\title{
Novel freedom of expression
}

\section{Loren Graham}

Soviet Fiction Since Stalin: Science, Politics and Literature. By Rosalind J. Marsh. Croom Helm/Barnes \& Noble: 1986. Pp.338. £25, \$28.50.

Does the Soviet Union suffer from the same grievous split between the scientific and literary cultures so graphically described many years ago by C.P. Snow in the Rede Lecture at Cambridge? Some evidence suggests that it does not, that scientists and creative artists have more in common in the Soviet Union than they do in most Western countries. Distinguished Soviet theoretical scientists, especially in physics and mathematics, have a tradition of defence of freedom for creativity in general. For example, in the waning years of Stalinism physicists such as Peter Kapitsa and Igor Tamm created and protected salons celebrating the arts; even today, over a year after Kapitsa's death, the walls of his famous Institute of Physical Problems in Moscow are lined with paintings that cannot be exhibited elsewhere in the Soviet Union.

Yet there is another split in the educated élite of the Soviet Union, one whose two opposing sides were defined some years ago by the West German scholar Arnold Buchholz as the "scientific literary intelligentsia" and the "technomanagerial intelligentsia". The first group takes as its primary goal "creativity", in whatever field - be it physics, poetry or art - and is united by opposition to the ideologists and censors of the regime. The second group has as its main aim the management of society and the economy; its members have in common a determination to defend and improve the existing Soviet order. Members of the first group often consider those in the second group to be philistine and dogmatic; those in the second group just as frequently consider the first group irresponsible and unpatriotic.

In recent years specialists on the Soviet Union have begun to debate this issue, but Rosalind Marsh, a lecturer in Slavonic Studies at Queen's University, Belfast, is the first person to convert debate into scholarship. In this book she has succeeded marvellously in laying bare the image of science and technology in Soviet fiction, and in the process she has enriched our knowledge both of the Soviet Union and of the relationship between the world of scientists and the world of artists. Her book places our understanding of the relationship between the two cultures in the Soviet Union on an entirely different and more sophisticated plane.

Marsh observes that many of the characteristics of the genius seeking truth (individualism, creativity, spiritual freedom) that are attributed to scientists in Soviet fiction are associated with artists in the West. She suggests that the reason for this difference is that such an artist would be too controversial in the Soviet Union in view of the Communist Party's continuing ideological supervision of art. Science, however, has in the post-Stalin years escaped from most of its ideological restrictions, and therefore can serve as a model for free creativity.

Science is admired and praised by both the Soviet regime and the non-conformist intellectuals, although for slightly different reasons: the regime wishes to benefit

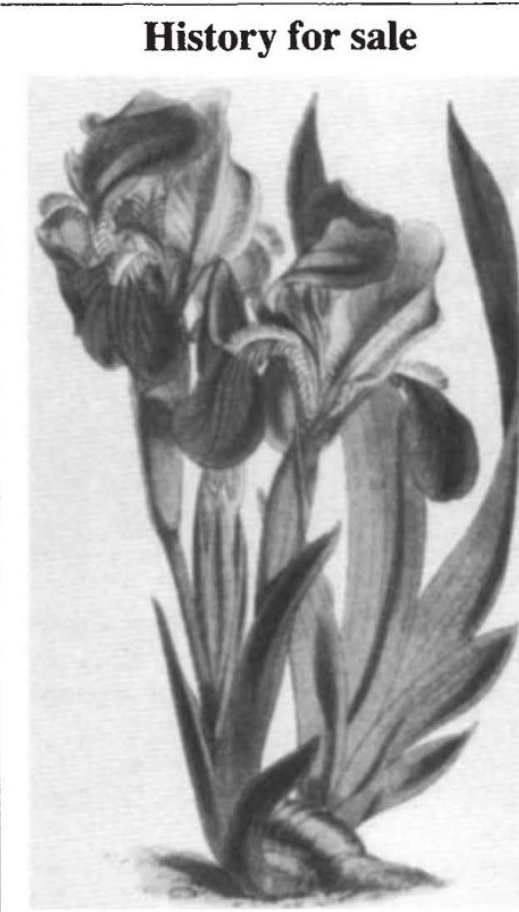

Illustration from The Botanical Magazine, a complete set of which (184 volumes containing 10,566 plates, all but three of them in colour) was on offer at Sotheby's, London, on 9 May. The periodical first appeared in 1787 and ran until 1983 when it became part of The Kew Magazine; among its editors were the founder William Curtis and, in the nineteenth century, W.J. Hooker and J.D. Hooker.

The set (estimated price $\$ 40,000$ $£ 50,000)$ failed to find a buyer.

Other properties at the sale were first editions of Charles Darwin's On the Origin of Species... (sold for $£ 1,980$ ), Robert Hooke's Micrographia (£2,750) and Sigmund Freud's Die Traumdeutung $(£ 1,430)$. from the practical applications of science for the economy and for national strength, while the non-conformist intellectuals yearn for free debate of social and political issues. Fiction involving scientists becomes for the non-conformist a surrogate for broader debates that are not allowed in a more literal form. As Marsh says, "Through the mouth of a character or by implication, writers are often able to suggest ideas which they could not express in their own names".

In the post-Stalin period, Soviet fiction dealing with science and technology has been the medium for raising a host of questions that are not permitted elsewhere. Is the space programme so expensive that it impoverishes the domestic economy? Has the collective farm system destroyed the peasants' pride in their work and love of the land? Is the centralized Soviet economy a drag on technological innovation? Does mind-numbing work on assembly lines alienate workers in the Soviet Union just as it does in the West? Is the emphasis on rapid industrialization polluting the Soviet environment? Is urbanization eroding traditional life and culture? And even: Are the causes of the threat of nuclear destruction not solely to be found in the West, but shared by the superpowers? Marsh explores all of these themes and many more, showing how science and technology in fiction is one of the most revealing mirrors available to us for viewing controversies in Soviet society. She makes a convincing case that scientists and engineers in novels are permitted greater latitude in their discussions of social issues than politicians ever would be.

An example of how a novel about technology can become an argument for reform is Ivan Dvoretsky's The Outsider (1972), in which the brash young engineer Cheshkov is horrified by the waste and inefficiency of a Leningrad factory and attempts, at one swoop, to eliminate laziness, corruption, truancy, drunkenness, falsification of records and outright theft of state property. At first Cheshkov causes a rebellion, and nearly loses his job, but eventually his radical reorganization of management and labour in the plant wins official support.

The prominent economist Academician A. Aganbegyan recognized that novels such as The Outsider are important in efforts to reform the Soviet economy. Writing in 1974, he proclaimed:

Economists now know what must be fought for. But public opinion has not sufficiently matured for many economic steps to be taken... . What economics asks of literature is that literature use all its resources to prepare public opinion for changes connected with the scientific and technological revolution.

Aganbegyan has now been transferred from his old post in Novosibirsk to 